\title{
Undernutrition modified metabolic responses to intramammary lipopolysaccharide but had limited effects on selected inflammation indicators in early-lactation cows
}

\author{
J. A. A. Pires, ${ }^{1 *}$ K. Pawlowski, ${ }^{1} \dagger$ J. Rouel, ${ }^{1}$ C. Delavaud, ${ }^{1}$ G. Foucras, ${ }^{2}$ P. Germon, ${ }^{3}$ and C. Leroux ${ }^{1,4}$ \\ ${ }^{1}$ INRA, Université Clermont Auvergne, VetAgro Sup, UMR Herbivores, F-63122 Saint-Genès-Champanelle, France \\ ${ }^{2}$ IHAP (Interactions Hôtes-Agents pathognènes), Université de Toulouse, ENVT, INRA, UMR 1225, F-31076 Toulouse cedex 03, France \\ ${ }^{3}$ ISP (Infectiologie et Santé Publique), INRA, Université de Tours, UMR 1282, 37380 Nouzilly, France \\ ${ }^{4}$ Department of Food Science and Technology, University of California Davis, Davis 95616
}

\section{ABSTRACT}

The objective was to assess effects of experimentally induced undernutrition on responses to an intramammary lipopolysaccharide (LPS) challenge in early-lactation cows. Starting at $24 \pm 3 \mathrm{~d}$ in milk, multiparous Holstein cows either received a ration containing $48 \%$ straw for $96 \mathrm{~h}$ to restrict nutrient intake (REST, $\mathrm{n}=$ 8 ) or were allowed ad libitum intake of a lactation diet $(\mathrm{CONT}, \mathrm{n}=9$ ). After $72 \mathrm{~h}$ on diet or after an equivalent period for CONT, $50 \mu \mathrm{g}$ of LPS (Escherichia coli 0111:B4) was injected into one healthy rear mammary quarter to induce an acute inflammation response. Blood samples were collected weekly until 7 wk of lactation, daily during feed restriction (or control), before and at 1, 2, 4, 6, 10, and $24 \mathrm{~h}$ relative to LPS injection. Foremilk quarter samples were collected before and at 4, 6,10 , and $24 \mathrm{~h}$ after LPS injection. Dry matter intake, milk yield, energy balance, plasma glucose, nonesterified fatty acids (NEFA), and $\beta$-hydroxybutyrate (BHB) concentrations did not differ between CONT and REST immediately before nutrient restriction in REST (least squares means at $\mathrm{d}-1$ were $21.8,39.0 \mathrm{~kg} / \mathrm{d},-2.5$ $\mathrm{MJ} / \mathrm{d}$, and 3.78, 0.415, $0.66 \mathrm{~m} M$, respectively) but were significantly altered at $72 \mathrm{~h}$ of nutrient restriction $(9.8$, $28.3 \mathrm{~kg} / \mathrm{d},-81.6 \mathrm{MJ} / \mathrm{d}$, and $2.77,1.672$, and $2.98 \mathrm{mM}$, respectively), when the LPS challenge was performed. The rectal temperature increment from baseline values in response to LPS did not differ, but cortisol increment was greater and cortisol response area under the curve (AUC) tended to be greater [202 vs. 122 (ng/ $\mathrm{mL}) \times 10 \mathrm{~h}$ ] for REST than CONT. No treatment differences were observed in foremilk IL-8, IL-1 $\beta$, tumor

Received July 26, 2018.

Accepted January 30, 2019

*Corresponding author: jose.pires@inra.fr

$\dagger$ Current address: Warsaw University of Life Sciences, Faculty of Veterinary Medicine, Department of Pathology and Veterinary Diagnostics, 02-776 Warsaw, Poland. necrosis factor- $\alpha$, and chemokine ( $\mathrm{C}-\mathrm{X}-\mathrm{C}$ motif) ligand 3 concentrations in response to LPS injection. Composite milk somatic cell count per milliliter $\left(6.919 \times 10^{6}\right.$ vs. $1.956 \times 10^{6}$ cells $/ \mathrm{mL}$ ) and total number of somatic cells secreted in milk per day were greater for REST than CONT during the day following LPS. Plasma glucose, urea, and insulin concentrations increased after the LPS challenge, suggesting establishment of insulin resistance and modifications of glucose metabolism to support acute inflammation in both CONT and REST. Nonetheless, nutrient-restricted cows had delayed plasma insulin and glucose responses to LPS, smaller insulin AUC but greater glucose AUC compared with CONT, despite the limited nutrient availability to sustain an inflammation response. Undernutrition altered peripheral metabolic responses to an intramammary LPS challenge but had limited effects on selected indicators of inflammation response in early-lactation cows. Key words: dairy cow, negative energy balance, inflammation, lipopolysaccharide (LPS)

\section{INTRODUCTION}

Dairy cows experience profound shifts in hormonal and nutritional status during the periparturient period, rely on extensive mobilization of body fat, proteins, and bone minerals to support the onset of lactation, and often present altered plasma metabolite and mineral profiles (Pires et al., 2013; Valldecabres et al., 2018). Concomitantly, multiple aspects of immune function are modified and the occurrence of metabolic disorders and inflammatory diseases peaks during this period. For instance, leukocyte function is impaired in early compared with mid lactation (Shuster et al., 1996) and in cows with increased markers of negative energy balance (Kremer et al., 1993; Hammon et al., 2006). Leukocyte dysfunction is associated with development of metritis and severity of experimental mastitis (Kremer et al., 1993; Shuster et al., 1996; Hammon et al., 
2006). Furthermore, clinical mastitis during early lactation may affect reproduction and functional longevity (Albaaj et al., 2017; Hertl et al., 2018).

Complex homeorhetic and homeostatic adaptations need to occur during early lactation to orchestrate the partitioning of limiting nutrients toward the mammary gland. These include the establishment of insulin resistance in peripheral tissues and enhanced hepatic glucose output via glycogenolysis and gluconeogenesis (Bell and Bauman, 1997; Doepel et al., 2009). Experimental acute immune activation imposes a glucose drain that may overwhelm the adaptive capacity of the animal and disrupt homeostasis (Kvidera et al., 2017). Accordingly, ovine genetic lines selected for divergent milk SCC also present divergent metabolic profiles in response to negative energy balance in early lactation. The high-SCC sheep experience a greater metabolic burden during experimental energy restriction than the low-SCC sheep, further suggesting a link between immune function and metabolic robustness (BouvierMuller et al., 2016).

Feed restriction models have been used extensively to study the ramifications of nutrient deficit, lipomobilization, and related metabolic deviations on biological functions at various lactation stages (Veenhuizen et al., 1991; Perkins et al., 2002; Moyes et al., 2009; Gross et al., 2011; Bjerre-Harpøth et al., 2012). On the other hand, LPS challenges have been used as a model to study the mechanisms and factors modulating gram-negative bacteria-associated mastitis in dairy cows (Paape et al., 2003; Schukken et al., 2011), including interactions with nutritional status (Perkins et al., 2002), diet fatty acid composition (Greco et al., 2015), and effects of immune activation on metabolic and mineral homeostasis (Waldron et al., 2003a,b; Kvidera et al., 2017). Challenges with LPS have the advantage of inducing repeatable, self-resolved inflammatory responses, with both local and systemic effects, while avoiding the adverse consequences of an infection (Hoeben et al., 2000; Vernay et al., 2012). Relatively few studies have focused on experimentally induced undernutrition, the resulting negative energy balance, and responses to intramammary immune challenges in vivo (Perkins et al., 2002; Moyes et al., 2009; Bouvier-Muller et al., 2016). Nonetheless, research using feed-restricted midlactation cows as an experimental model has failed to show unequivocal associations between undernutrition and alterations of the immune response at the wholeanimal level (Perkins et al., 2002; Moyes et al., 2009).

Immune dysfunction in early-lactation cows is driven in part by the prioritization of nutrient partitioning toward milk secretion and altered metabolic milieu resulting from intense lipomobilization and ketosis, and potential deficiencies in key nutrients such as glucose, calcium, and specific AA (Kremer et al., 1993; Hammon et al., 2006; Martinez et al., 2014; Moyes, 2015). However, large nutrient imbalances typical of early lactation are difficult to reproduce later in lactation via feed restriction. For instance, the metabolic and hormonal responses to severe nutrient restriction are of lesser amplitude after peak lactation compared with early lactation (Gross et al., 2011; Bjerre-Harpøth et al., 2012). Plasma BHB increased when nutrient intake was restricted by feeding a high-straw diet in earlylactation cows, but was not affected in mid and late lactation cows, despite marked negative energy balance and corresponding shifts in plasma glucose and NEFA (Bjerre-Harpøth et al., 2012). We hypothesized that experimentally induced undernutrition would modify animal responses to mammary inflammation in early-lactation cows. A high-straw diet was used as a restriction model because its low nutrient density and digestibility decrease nutrient intake without the need to limit the quantity of feed offered. The experiment was performed during early lactation because the metabolic deviations in response to nutritional challenges are greatest during this period. The objective was to assess the effects of nutrient restriction on whole-animal responses to an intramammary LPS challenge in early-lactation cows.

\section{MATERIALS AND METHODS}

\section{Animals, Diets, LPS Challenge, and Housing}

All procedures were approved by the regional ethics committee on animal experimentation (APAFIS \#2018062913565518).

Seventeen multiparous Holstein-Friesian cows were studied from the last $3 \mathrm{wk}$ of gestation until $7 \mathrm{wk}$ postpartum. From 24 to $27 \pm 3$ DIM (mean \pm SD), cows were either allowed continuous ad libitum intake of a lactation TMR (CONT; n = 9) or were fed a TMR containing $48 \%$ of chopped barley straw (DMbasis) during $96 \mathrm{~h}$ (restricted, REST; $\mathrm{n}=8$ ). Diet ingredient and nutrient composition are presented in Table 1. Cows were selected based on previous lactation performance, health records, and expected calving date and were randomly allocated to treatments before the initiation of the experiment.

At $72 \mathrm{~h}$ of differential diet between CONT and REST, one healthy rear mammary quarter was injected with $50 \mu \mathrm{g}$ of LPS (Escherichia coli O111:B4, Ultrapure LPS-EB, InvivoGen, Toulouse, France) diluted in 10 $\mathrm{mL}$ of sterile saline (CDM Lavoisier, Paris, France) containing $0.5 \mathrm{mg} / \mathrm{mL}$ of BSA (cell culture-grade, endotoxin-free, A9576, Sigma-Aldrich, Saint-QuentinFallavier, France). After morning milking, teats were cleaned and the tips swabbed with cotton containing 
Table 1. Diet ingredient, nutrient, and fatty acid (FA) composition ${ }^{1}$

\begin{tabular}{|c|c|c|c|}
\hline \multirow[b]{2}{*}{ Item } & \multirow[b]{2}{*}{ Dry period ${ }^{2}$} & \multicolumn{2}{|c|}{ Lactation } \\
\hline & & Control & Restriction \\
\hline \multicolumn{4}{|l|}{ Ingredient ( $\%$ of $\mathrm{DM})$} \\
\hline Corn silage & 43.5 & 29.0 & 16.1 \\
\hline Grass silage & 40.0 & 25.5 & 14.9 \\
\hline Barley straw & 5.5 & 3.5 & 48.2 \\
\hline Corn grain & 8.2 & 24.2 & 4.0 \\
\hline Soybean meal & 2.8 & 16.9 & 15.4 \\
\hline Mineral and vitamin $\operatorname{mix}^{3}$ & - & 0.9 & 1.4 \\
\hline Forage:concentrate ratio & $89: 11$ & $58: 42$ & $79.2: 20.8$ \\
\hline \multicolumn{4}{|c|}{ Nutrient composition (\% of DM) } \\
\hline Net energy $(\mathrm{MJ} / \mathrm{kg}$ of $\mathrm{DM})$ & 6.49 & 7.10 & 5.16 \\
\hline $\mathrm{PDI}^{4}(\mathrm{~g} / \mathrm{kg}$ of $\mathrm{DM})$ & 76 & 106 & 93 \\
\hline $\mathrm{CP}$ & 12.7 & 17.4 & 12.2 \\
\hline NDF & 42.0 & 33.5 & 57.5 \\
\hline $\mathrm{ADF}$ & 23.7 & 15.3 & 33.9 \\
\hline Fat & 2.2 & 2.1 & 1.2 \\
\hline Starch & 19.0 & 27.5 & 8.6 \\
\hline Ash & 7.3 & 6.5 & 8.2 \\
\hline \multicolumn{4}{|c|}{ Fatty acid composition ( $\mathrm{g} / 100 \mathrm{~g}$ of FA) } \\
\hline C16:0 & 16.49 & 15.98 & 20.76 \\
\hline C18:0 & 1.94 & 2.27 & 3.01 \\
\hline cis-9 C18:1 & 14.36 & 19.60 & 17.2 \\
\hline $\mathrm{C} 18: 2 \mathrm{n}-6$ & 33.56 & 40.58 & 29.60 \\
\hline C18:3n-3 & 20.00 & 12.26 & 11.92 \\
\hline Other & 13.65 & 9.31 & 17.7 \\
\hline
\end{tabular}

${ }^{1}$ Multiparous Holstein cows were allowed ad libitum intake throughout the study (control, $\mathrm{n}=9$ ) or underwent $4 \mathrm{~d}$ of nutrient restriction (restricted, $\mathrm{n}=8$ ) by receiving a ration composed of $48 \%$ (DM basis) straw from 24 to $27 \pm 3$ DIM (mean $\pm \mathrm{SD})$.

${ }^{2}$ During 4 wk before expected calving.

${ }^{3}$ Mineral and vitamin mix contained $2.5 \% \mathrm{P}, 20 \% \mathrm{Ca}, 4.5 \% \mathrm{Mg}, 3.5 \% \mathrm{Na}, 1 \% \mathrm{~S}, 400,000 \mathrm{IU} / \mathrm{kg}$ of vitamin A, $120,000 \mathrm{IU} / \mathrm{kg}$ of vitamin $\mathrm{D}_{3}, 1,600 \mathrm{IU} / \mathrm{kg}$ of vitamin E, $1.3 \mathrm{~g} / \mathrm{kg}$ of Cu, $5 \mathrm{~g} / \mathrm{kg}$ of Zn, $3.5 \mathrm{~g} / \mathrm{kg}$ of Mn, $90 \mathrm{mg} /$ $\mathrm{kg}$ of I, $36 \mathrm{mg} / \mathrm{kg}$ of Co, and $20 \mathrm{mg} / \mathrm{kg}$ of Se; Galaphos Midi duo granule, CCPA (Aurillac, France).

${ }^{4}$ Protein truly digestible in the small intestine (INRA, 2007).

$70 \%$ ethanol. The LPS solution, prepared extemporaneously in a sterile environment, was injected into the teat cistern via the teat canal, using a sterile disposable syringe fitted with a teat cannula, and the udder was massaged briefly.

Cows were housed in freestalls equipped with individual feed bunks and automatic gates, except from 1 wk before and until $3 \mathrm{~d}$ after the LPS challenge, when they were housed in a tiestall barn to acclimate and to facilitate frequent sampling and animal care. Cows were milked twice daily at approximately 0900 and 1600 $\mathrm{h}$ and had fresh feed offered once daily after morning milking and free access to drinking water.

\section{Phenotyping Early Lactation and Responses to Undernutrition}

Offered feed and refusals were weighed and subsamples were collected $4 \mathrm{~d} /$ wk to determine DM content after $48 \mathrm{~h}$ at $80^{\circ} \mathrm{C}$ and calculate DMI (Lerch et al., 2012). Pre- and postpartum TMR samples were collected weekly, pooled, and analyzed for nutrient com- position by wet chemistry (Table 1). Energy balance was estimated as energy intake minus requirements for maintenance and production, calculated according to the INRA system (INRA, 2007). Milk yield was recorded daily, milk samples were collected at 4 consecutive milkings each week and analyzed for composition and SCC by near-infrared spectrometry and Fossomatic FC method (Foss Electric, Hillerød, Denmark), respectively. Weighted milk component means were computed according to p.m./a.m. production. To characterize the responses to feed restriction, DMI and milk composition were measured daily in both groups from $2 \mathrm{~d}$ before restriction until $7 \mathrm{~d}$ after refeeding the lactation TMR to cows in the REST group. Body weight and BCS (6-point, 0 to 5 scale) were recorded weekly, $1 \mathrm{~d}$ before diet change, and on the last day of restriction.

Blood samples were collected from coccygeal vessels before the morning feeding on Wednesday of wk -3 , $-2,-1,1,2,3,5,6$, and 7 relative to calving, corresponding to $-18,-11,-4,8,15,21,35,42$, and 48 DIM, respectively. The first postpartum blood sample was collected after 3 DIM. Samples were collected from 
jugular veins at $-24,24$, and $48 \mathrm{~h}$ relative to initiation of restriction and at equivalent periods for CONT.

\section{Phenotyping Responses to LPS Challenge}

In addition to weekly SCC analyses of composite milk, cows were further screened for mastitis 1 wk prior to and again immediately before the milking preceding the LPS challenge using the California Mastitis Test (Neodis, Rambouillet, France) and SCC analyses of foremilk samples collected from the rear quarters (Galilait, Theix, Saint Genès-Champanelle, France). Only cows with $\mathrm{SCC}<100,000$ cells $/ \mathrm{mL}$ in a rear quarter were included in the study. Foremilk samples were collected from the LPS-challenged quarters immediately before the morning milking that preceded the LPS injection (time 0 ), and at 4, 6, 10, and $24 \mathrm{~h}$ after LPS injection. These quarter milk samples were analyzed by ELISA for IL-8, tumor necrosis factor (TNF)- $\alpha$, chemokine (C-X-C motif) ligand 3 (CXCL3) and IL1- $\beta$. For the ELISA bovine (b)CXCL3 and bIL-8 assays, the sequence of incubation steps, all performed at room temperature, was affinity-purified antibody $(\mathbf{A b})$ to C-terminal peptide of bCXCL3 or bIL-8 $(2 \mu \mathrm{g} / \mathrm{mL})$ in PBS overnight; blocking of the plate with $0.5 \%$ gelatin in PBS for $1 \mathrm{~h}$; incubation at the appropriate dilution or a series of 2-fold dilutions of standard bCXCL3 or bIL-8 for $2 \mathrm{~h}$; biotinylated IgG fraction of rabbit antiserum to recombinant bCXCL3 $(1 \mu \mathrm{g} / \mathrm{mL})$ or mouse $\mathrm{mAb}$ to ovine IL-8 $(0.5 \mu \mathrm{g} / \mathrm{mL}$, clone $8 \mathrm{M} 6$; Bio-Rad Laboratories, Hercules, CA) for $1 \mathrm{~h}$; avidin-peroxidase conjugate (Molecular Probes, Thermo Fisher Scientific, Rockford, IL) or peroxidase-conjugated goat Ab to mouse IgG (Jackson Immunoresearch Laboratories, West Grove, PA) diluted 1:20,000 for $1 \mathrm{~h}$, and finally 3,3',5,5'-tetramethylbenzidine (TMB) ELISA substrate. Commercial ELISA were used for TNF- $\alpha$ (R\&D Systems, Minneapolis, MN) and IL1- $\beta$ (Thermo Fisher Scientific) according to the manufacturers' instructions. Several foremilk samples could not be analyzed for SCC for technical reasons; therefore, quarter milk SCC data were excluded to prevent potential bias. The whole-udder composite milk SCC and total number of somatic cells secreted per day were analyzed instead. Total number of somatic cells secreted in milk per day was calculated by converting milk yield from kilograms to liters per day (considering a standard density of 1.033), and multiplying the volume of milk by SCC per milliliter.

Jugular blood samples were collected at $-1,-0.5,1$, $2,4,6,10$, and $24 \mathrm{~h}$ relative to LPS injection. Plasma concentrations at $72 \mathrm{~h}$ relative to initiation of feed restriction were calculated by averaging values at 1 and $0.5 \mathrm{~h}$ before LPS administration. Rectal temperature was recorded at the time of each blood sampling on the day of LPS injection using an electronic thermometer (Veterinär-Thermometer SC 12, SCALA Electronic GmbH, Stahnsdorf, Germany).

All blood samples were drawn into evacuated tubes containing EDTA $(1.95 \mathrm{mg} / \mathrm{mL}$; Terumo Europe NV, Leuven, Belgium) and centrifuged at $1,400 \times g$ for 15 min at $4^{\circ} \mathrm{C}$. Plasma was conserved at $-20^{\circ} \mathrm{C}$ until analysis for glucose (glucose oxidase method), BHB (D- $\beta$-hydroxybutyrate-dehydrogenase method), urea (glutamate dehydrogenase method; Thermo Electron SAS, Courtaboeuf Cedex, France), and NEFA (acylCoA synthase method; Fujifilm Wako Chemicals Europe GmbH, Neuss, Germany) using an automatic analyzer (Arena 20XT, Thermo Fisher Scientific, Cergy Pontoise, France), insulin using a RIA as previously described (Lerch et al., 2012), and cortisol (Boissy and Bouissou, 1994). Intra-and interassay coefficients of variation were 1.4 and $3.1 \%$ for glucose, 2.1 and $3.0 \%$ for NEFA, 4.5 and $5.5 \%$ for BHB, 5.9 and $8.5 \%$ for urea, and 6.9 and $11.8 \%$ for insulin, respectively.

Biopsies of liver and mammary gland (LPS-infused rear quarter) were performed $24 \mathrm{~h}$ after LPS injection, after plasma and quarter milk collection, reported elsewhere.

\section{Statistical Analyses and Calculations}

Statistical analyses were performed using SAS (version 9.4; SAS Institute Inc., Cary, NC) separately for data collected prepartum, postpartum, and during the time of LPS challenge. Repeated-measures data were analyzed by mixed models that included the fixed effects of diet, time, and diet $\times$ time interaction, the random effect of cow, and Kenward-Roger adjustment for calculation of denominator degrees of freedom. The Schwarz Bayesian criterion was used to compare the fitting of different covariance structures, including spatial power, first-order autoregressive $[\mathrm{AR}(1)]$, heterogeneous first-order autoregressive $[\mathrm{ARH}(1)]$, and compound symmetry (CS). Heterogeneous variance for each diet was tested whenever suggested by residual plots. Significant interactions of diet $\times$ time were explored using the SLICE and PDIFF options of the LSMEANS statement. Areas under the curve (AUC) during the 10 and $24 \mathrm{~h}$ post-LPS challenge were calculated by the incremental (positive and negative) method for plasma metabolites and insulin, and by the positive incremental method for cortisol, after discounting for baseline concentrations (Cardoso et al., 2011) using Excel (2013; Microsoft Corp., Redmond, WA) and analyzed as nonrepeated variables. Basal plasma metabolite and insulin concentrations were calculated by averaging values from samples collected at 1 and $0.5 \mathrm{~h}$ before 
LPS injection. Logarithmic transformation of response variables was used whenever needed to comply with the assumptions of normality and homoscedasticity of residuals. When transformation was necessary, least squares means (LSM) and standard error of the mean (SEM) were estimated from untransformed values, whereas $P$-values reflect statistical analysis of transformed data. Values reported are LSM and SEM, unless otherwise stated. The significance level was predefined as $P \leq 0.05$, and trends toward significance at $0.05<$ $P \leq 0.10$.

\section{RESULTS}

\section{Prepartum}

Cows in the REST group tended $(P=0.10)$ to have greater BCS (2.84 vs. $2.47 \pm 0.16$; Supplemental Figure S1A; https://doi.org/10.3168/jds.2018-15446) and plasma BHB (0.56 vs. $0.49 \pm 0.03 \mathrm{mM}$ ) than cows in the CONT group during the 3 wk prepartum. Plasma
NEFA concentration increased during late gestation (time effect, $P=0.01$ ) and was $0.092,0.124$, and 0.183 $\pm 0.021 \mathrm{~m} M$ in wk $-3,-2$, and -1 relative to calving, respectively. Dry matter intake was $15.2,14.8$, and 13.7 $\pm 0.53 \mathrm{~kg} / \mathrm{d}$ (time effect, $P=0.11$ ) during the same period.

\section{Early Lactation and Responses to Undernutrition}

Postpartum DMI, milk yield, fat and protein contents and yields, $\mathrm{NE}_{\mathrm{L}}$ balance, $\mathrm{BCS}$, and $\mathrm{BW}$ did not differ between the groups before the diet change (Figure 1A, 1B and Supplemental Figures S1A, S1B, S2A, S2B, S2C and S2D; https://doi.org/10.3168/jds.2018 -15446). Feeding a TMR containing $48 \%$ straw induced a sudden decrease in DMI and negative energy balance, with milk yield decreasing significantly on the second day of restriction and thereafter (Figure 1A, 1B, and $1 \mathrm{C})$.

Plasma concentrations of NEFA, glucose, urea, and insulin did not differ until diet change at $24 \pm 3$ DIM
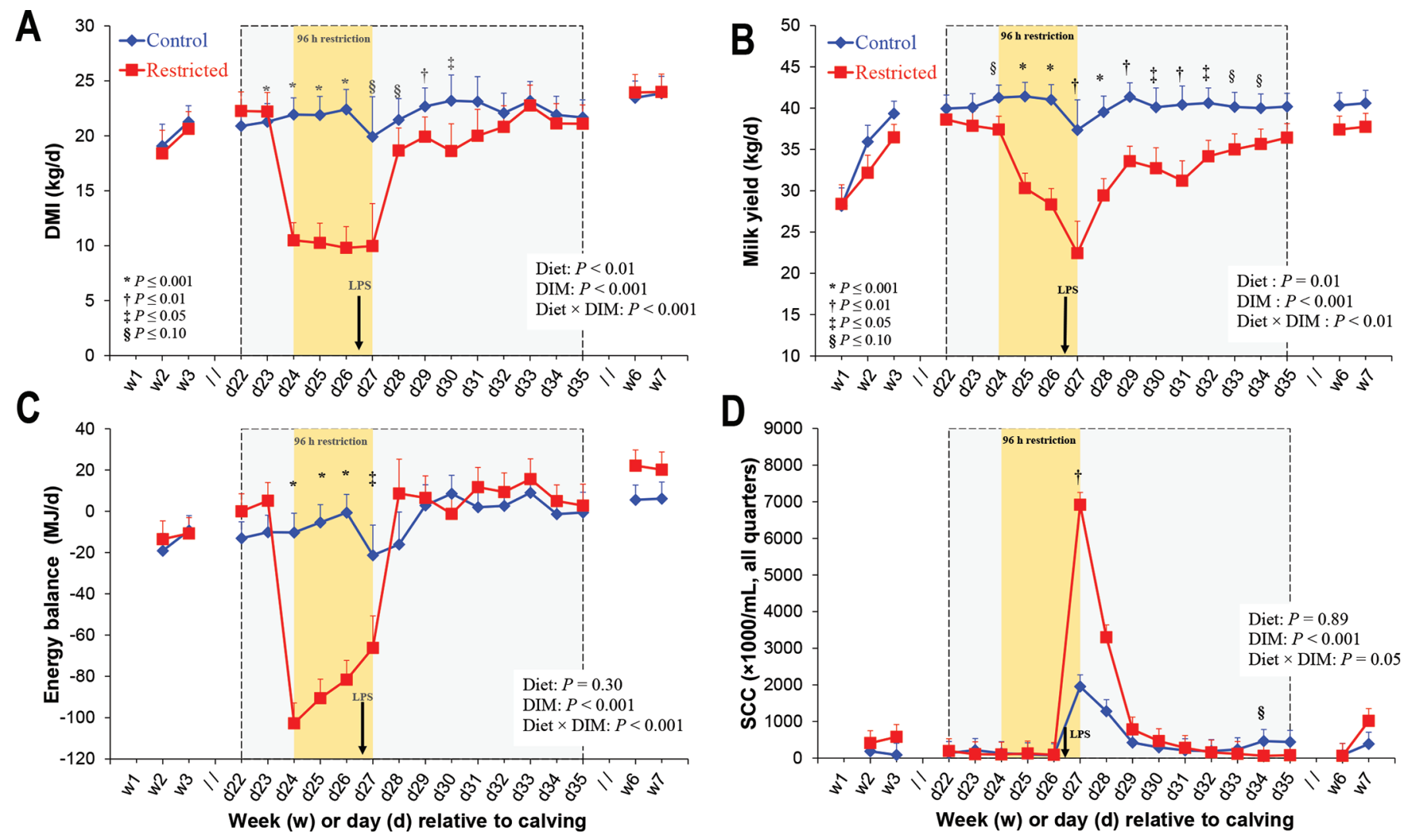

Figure 1. Dry matter intake (A), milk yield (B), energy balance (C), and SCC (D). Multiparous Holstein cows were allowed ad libitum intake of a regular diet throughout the study (control, $\mathrm{n}=9$ ) or underwent $4 \mathrm{~d}$ of nutrient restriction (restricted, $\mathrm{n}=8$ ) by receiving a ration composed of $48 \%$ (DM basis) straw from 24 to $27 \pm 3$ DIM (mean \pm SD). One healthy rear mammary quarter was injected with $50 \mu \mathrm{g}$ of LPS (Escherichia coli O111:B4) $72 \mathrm{~h}$ after initiation of dietary treatments. P-values for SCC reflect statistical analysis with log-transformed data. Values are $\mathrm{LSM} \pm \mathrm{SEM}$. 
(Figure 2A, 2C, 2D, and 2E). Nonetheless, a trend for greater BHB was observed in the first week of lactation for REST compared with CONT cows (Figure 2B). Per design, after nutrient restriction, the REST cows presented significantly greater concentrations of plasma NEFA, BHB, and urea, and lower concentrations of glucose and insulin than CONT cows (Figure 2 ). Therefore, the metabolic profile was profoundly altered at $72 \mathrm{~h}$ after dietary treatments (Table 2, Figure 2). Plasma cortisol did not differ between REST and CONT groups during the first $72 \mathrm{~h}$ of dietary treatments (data not shown).

Milk composition and component yields are presented in Supplemental Figure S2 (https://doi.org/10.3168/jds .2018-15446). Milk fat percentage increased during feed restriction and returned to pre-restriction concentrations on the same day of refeeding the regular lactation diet (Supplemental Figure S2A). Lactose content was depressed during the last $3 \mathrm{~d}$ of restriction (Supplemental Figure S2E). Milk, fat, protein, and lactose yields decreased in REST and returned to pre-restriction values within $7 \mathrm{~d}$ after refeeding (Supplemental Figures $\mathrm{S} 2 \mathrm{~B}, \mathrm{~S} 2 \mathrm{D}$, and S2F).

Body condition score decreased postpartum but did not differ significantly between treatments throughout the study (Supplemental Figure S1A). Nonetheless, BW was lower at the end of the restriction period for REST than control $(P=0.01$; Supplemental Figure S1B), but BW differences were not observed thereafter.

\section{Responses to Intramammary LPS Challenge}

The inflammatory challenge modified some production variables during the $24 \mathrm{~h}$ following the intramammary LPS injection in CONT cows. Control cows showed a decrease in DMI $(-2.5 \mathrm{~kg}$ of DM; $P<0.01$; Figure 1A), milk protein yield $(P<0.01)$, and lactose content $(P=0.02)$, and a tendency for decreased protein content $(P=0.07)$ on the day of the LPS challenge (Supplemental Figures S2C, S2D, and S2E). In CONT cows, milk fat content was greatest during the $48 \mathrm{~h}$ following LPS injection $(P<0.05)$ compared with all other DIM, and milk fat yield increased $(P<0.05)$ during the same period (Supplemental Figures S2A and S2B). In REST cows, milk production tended to decrease $(-5.9 \mathrm{~kg} ; P=0.07)$ on the day following the LPS challenge (Figure 1B). Milk fat content increased $(P=0.04)$, whereas lactose concentration and protein yield decreased $(P<0.001)$ on the day of LPS challenge, as observed for CONT (Supplemental Figures S2A, S2E, and S2D, respectively).

Composite milk SCC increased sharply on the day of LPS challenge in both CONT and REST cows (Figure $1 D)$, but SCC was greater for REST $\left(6.91 \times 10^{6}\right.$ vs.
$1.91 \times 10^{6} \pm 337 \times 10^{3}$ cells $/ \mathrm{mL}, P=0.01$; diet $\times$ time interaction, $P=0.04)$. Furthermore, REST cows secreted a greater total number of somatic cells in milk than CONT on the day of LPS injection $\left(1.35 \times 10^{11}\right.$ vs. $0.67 \times 10^{11} \pm 0.203 \times 10^{11}$ cells; $\left.P=0.03\right)$. Composite milk SCC returned to prechallenge values after 31 and 34 DIM for REST and CONT, respectively.

The increment in rectal temperature above pre-LPS challenge values and measured rectal temperature are presented in Figure 3A and Supplemental Figure S3A (https://doi.org/10.3168/jds.2018-15446), respectively. Rectal temperature after $72 \mathrm{~h}$ of diet treatments, measured before LPS injection, did not differ between groups (38.3 vs. $37.8 \pm 0.2^{\circ} \mathrm{C}$ for CONT and REST, respectively; Supplemental Figure S3A). For both treatments, temperature increased significantly at 4,6 , and $10 \mathrm{~h}$ after LPS injection (Figure 3A, Supplementary Figure S3A). The average temperature during the day of LPS challenge (measured at $0,1,2,4,6,10$, and 24 h) was lower for REST than for CONT (38.4 vs. $38.9 \pm$ $0.14^{\circ} \mathrm{C}, P=0.03$; Supplemental Figure S3A). Nonetheless, restriction did not alter the temperature increment relative to pre-LPS challenge values (Figure 3A). The maximal temperature increment was $2.1 \pm 0.15^{\circ} \mathrm{C}$, at 6 $\mathrm{h}$ after LPS injection.

Plasma cortisol increment from baseline in response to LPS and plasma cortisol concentrations are presented in Figure 3B and Supplementary Figure 3B (https:/ /doi.org/10.3168/jds.2018-15446), respectively. Plasma cortisol concentrations did not differ between REST and CONT before the LPS challenge (19.1 vs. $24.5 \pm$ $7.3 \mathrm{ng} / \mathrm{mL}$, respectively), peaked in samples collected 4 $\mathrm{h}$ after LPS injection $(64.5 \pm 5.0 \mathrm{ng} / \mathrm{mL})$, and returned to baseline at $10 \mathrm{~h}$ after injection (Supplemental Figure S3B). Nonetheless, REST had a greater cortisol increment above baseline in response to LPS than CONT $(P=0.05$; Figure $3 \mathrm{~B})$ and greater cortisol response AUC (344 vs. $175 \mathrm{ng} / \mathrm{mL} \times 24 \mathrm{~h}, P=0.02$; Table 2$)$. Milk IL-8, IL-1 $\beta$, TNF- $\alpha$, and CXCL3 concentrations did not differ between CONT and REST in foremilk samples collected from the LPS-injected quarters immediately before and at $4,6,10$, and $24 \mathrm{~h}$ relative to LPS challenge (Figure 3C, 3D, 3E, and 3F). Milk CXCL3 AUC in response to LPS challenge tended to be lower for REST than CONT during the $10 \mathrm{~h}$ after the challenge $\left(P=0.08 ; 9.05 \times 10^{3}\right.$ vs. $11.87 \times 10^{3} \pm 1.33$ $\times 10^{3} \mathrm{ng} / \mathrm{mL} \times 10 \mathrm{~h}$, respectively). Plasma insulin and metabolite responses to LPS challenge are presented in Table 2 and Figure 4A, 4B, 4C, and 4D. Plasma insulin concentration increased for both CONT and REST after LPS challenge (time effect, $P<0.001$; Figure 4A). Nonetheless, for CONT, insulin concentration was significantly greater than basal at $1 \mathrm{~h}$ after LPS challenge and reached maximal concentration after 6 
$\mathrm{h}$, with a 2.7 -fold increase compared with prechallenge values. For REST, the maximal insulin concentration was reached after $10 \mathrm{~h}$, with a 1.9-fold increase compared with pre-LPS challenge concentrations. There- fore, insulin AUC in response to LPS challenge was smaller in REST than in CONT cows $(P<0.001$, Table 2 ). Nonetheless, absolute changes in NEFA, BHB, and glucose were greater in the REST group, as shown by
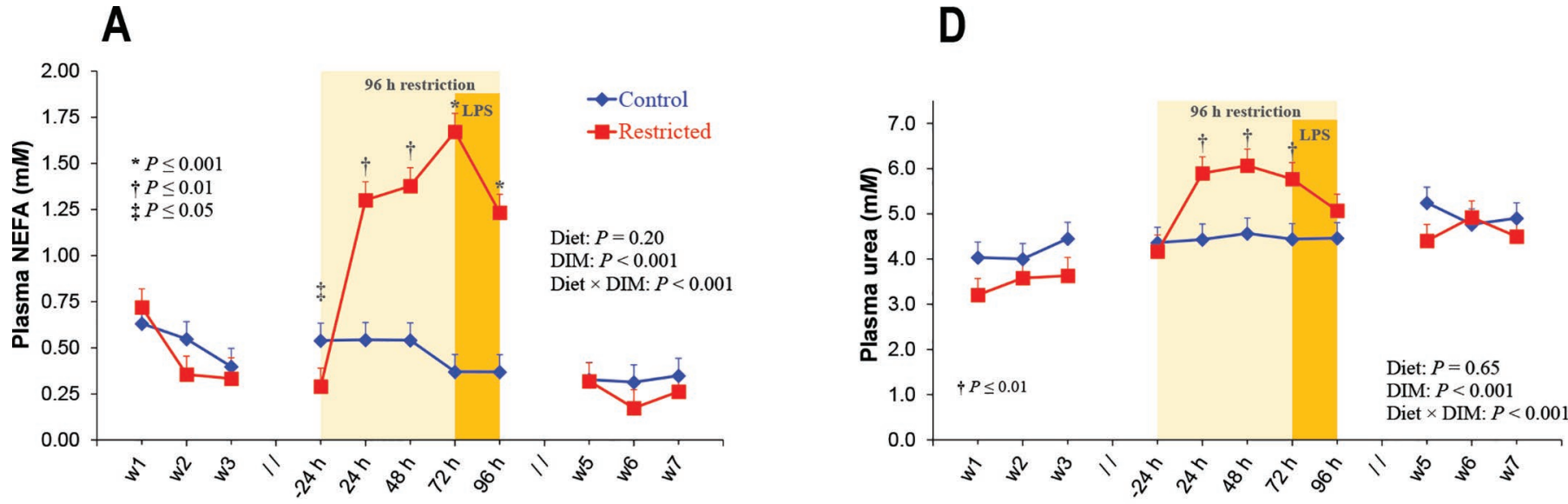

B

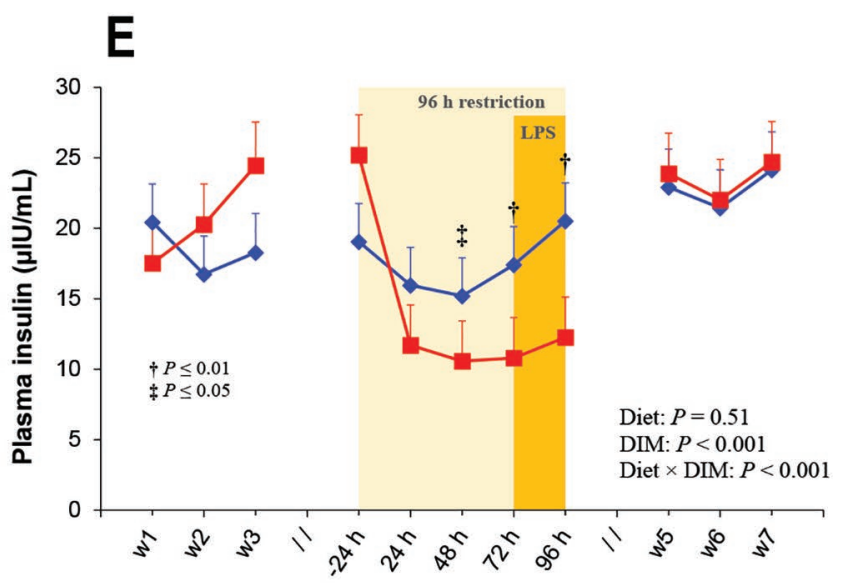

Week $(w)$ relative to calving or hour $(h)$ of feed restriction

C

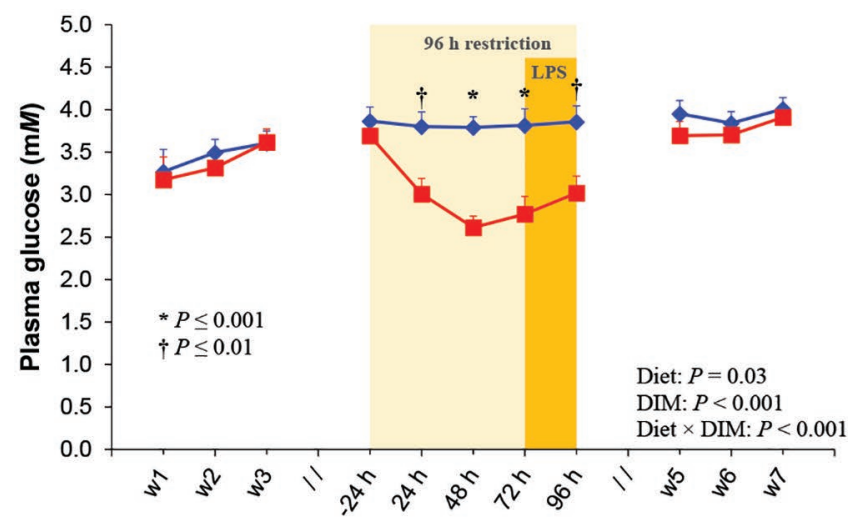

Week $(w)$ relative to calving or hour $(h)$ of feed restriction

Figure 2. Plasma nonesterified fatty acids (NEFA; A), BHB (B), glucose (C), urea (D), and insulin (E) concentrations. Multiparous Holstein cows were allowed ad libitum intake of a regular diet throughout the study (control, $\mathrm{n}=9$ ) or underwent $4 \mathrm{~d}$ of nutrient restriction (restricted, $\mathrm{n}=8$ ) by receiving a ration composed of $48 \%$ (DM basis) straw from 24 to $27 \pm 3$ DIM (mean $\pm \mathrm{SD}$ ). One healthy rear mammary quarter was injected with $50 \mu \mathrm{g}$ of LPS (Escherichia coli O111:B4) $72 \mathrm{~h}$ after initiation of dietary treatments. Values are LSM \pm SEM. 
AUC in Table 2. Plasma glucose was lower for REST than CONT on the day of LPS challenge (diet effect: $P$ $=0.02$; Figure $4 \mathrm{~B}$ ). When looking at time effects within each dietary treatment, plasma glucose concentrations increased over time for REST cows, exceeding baseline values at $10 \mathrm{~h}$ post-LPS injection $(P<0.01$; Figure $4 \mathrm{~A})$. Meanwhile, in the CONT group, glucose concentration initially decreased below baseline at $4 \mathrm{~h}(P<0.01)$ and rebounded above baseline at $10 \mathrm{~h}(P<0.05$; Figure 4A). Plasma NEFA concentration decreased sharply after LPS, from 1.672 and $0.371(P<0.001)$ to a nadir of $0.599 \pm 0.12$ and $0.101 \pm 0.10 \mathrm{~m} M$ at $4 \mathrm{~h}$ after injection, for REST and CONT, respectively, corresponding to 36 and $22 \%$ of prechallenge concentrations (Figure $4 \mathrm{C}$; diet and diet $\times$ time interaction, $P<0.001)$. In the REST group, plasma BHB was $2.98 \mathrm{~m} M$ before the LPS challenge and decreased significantly between 1 and $10 \mathrm{~h}$ after LPS injection, reaching a nadir of 1.78 $\pm 0.43 \mathrm{~m} M$ at $10 \mathrm{~h}$. In contrast, BHB was $0.69 \mathrm{~m} M$ before LPS injection in CONT, increased significantly above baseline between 1 and $10 \mathrm{~h}$ after LPS, reaching $1.23 \pm 0.22 \mathrm{mM}$ at $6 \mathrm{~h}$ post-challenge (diet and diet $\times$ time interaction, $P \leq 0.001$; Figure $4 \mathrm{D})$. Plasma urea concentration increased over time after LPS injection $(P<0.01)$ for both CONT and REST groups, and was significantly greater at 1,2 , and $4 \mathrm{~h}$ post-LPS challenge compared with before LPS challenge. A diet $\times$ time interaction was not observed during this period $(P=$ 0.71 ; data not shown). At $24 \mathrm{~h}$ after LPS challenge (corresponding to $96 \mathrm{~h}$ of dietary treatments), plasma insulin, BHB, and glucose had returned to pre-LPS challenge concentrations for both CONT and REST, whereas in REST, plasma NEFA and urea tended to decrease below the pre-LPS challenge concentrations.

\section{DISCUSSION}

This study assessed whether undernutrition and resulting metabolic imbalance modify the inflammatory response in early-lactation cows, as previous research involving mid-lactation cows showed limited effects of undernutrition on animal-level responses to LPS and Streptococcus uberis challenges (Perkins et al., 2002; Moyes et al., 2009). Despite the extreme negative en-

Table 2. Effects of nutrient restriction on plasma cortisol, insulin and metabolite responses to LPS challenge in early-lactation cows $^{1}$

\begin{tabular}{|c|c|c|c|c|}
\hline \multirow[b]{2}{*}{ Item $^{2}$} & \multicolumn{2}{|c|}{ Treatment } & \multirow[b]{2}{*}{ SEM } & \multirow[b]{2}{*}{$P$-value } \\
\hline & Control & Restricted & & \\
\hline \multicolumn{5}{|l|}{ Cortisol } \\
\hline $72 \mathrm{~h}(\mathrm{ng} / \mathrm{mL})$ & 24.5 & 19.1 & 5.8 & 0.51 \\
\hline $\mathrm{AUC}_{10 \mathrm{~h}}$ & 122 & 202 & 32 & 0.09 \\
\hline $\mathrm{AUC}_{24 \mathrm{~h}}$ & 175 & 344 & 48 & 0.02 \\
\hline \multicolumn{5}{|l|}{ Insulin } \\
\hline $72 \mathrm{~h}(\mu \mathrm{IU} / \mathrm{mL})$ & 17 & 11 & 1.6 & 0.009 \\
\hline $\mathrm{AUC}_{10 \mathrm{~h}}$ & 174 & 42 & 21 & $<0.001$ \\
\hline $\mathrm{AUC}_{24 \mathrm{~h}}$ & 339 & 120 & 44 & 0.002 \\
\hline \multicolumn{5}{|l|}{ Glucose } \\
\hline $72 \mathrm{~h}(\mathrm{~m} M)$ & 3.83 & 2.78 & 0.23 & 0.005 \\
\hline $\mathrm{AUC}_{10 \mathrm{~h}}$ & -0.94 & 3.56 & 0.94 & 0.003 \\
\hline $\mathrm{AUC}_{24 \mathrm{~h}}$ & 1.22 & 11.78 & 3.00 & 0.02 \\
\hline \multicolumn{5}{|c|}{ Nonesterified fatty acids } \\
\hline $72 \mathrm{~h}(\mathrm{~m} M)$ & 0.37 & 1.67 & $0.05-0.17$ & $<0.001$ \\
\hline $\mathrm{AUC}_{10 \mathrm{~h}}$ & -1.96 & -9.05 & $0.36-9.05$ & 0.002 \\
\hline $\mathrm{AUC}_{24 \mathrm{~h}}$ & -2.76 & -19.31 & $0.88-3.86$ & $<0.001$ \\
\hline \multicolumn{5}{|l|}{ BHB } \\
\hline $72 \mathrm{~h}(\mathrm{~m} M)$ & 0.69 & 2.98 & $0.12-0.47$ & $<0.001$ \\
\hline $\mathrm{AUC}_{10 \mathrm{~h}}$ & 3.68 & -6.05 & 1.51 & $<0.001$ \\
\hline $\mathrm{AUC}_{24 \mathrm{~h}}$ & 6.37 & -14.68 & 3.95 & 0.002 \\
\hline \multicolumn{5}{|l|}{ Urea } \\
\hline $72 \mathrm{~h}(\mathrm{~m} M)$ & 4.44 & 5.77 & $0.19-0.54$ & 0.03 \\
\hline $\mathrm{AUC}_{10 \mathrm{~h}}$ & 2.26 & -1.23 & 1.26 & 0.06 \\
\hline $\mathrm{AUC}_{24 \mathrm{~h}}$ & 0.15 & -12.63 & 3.35 & 0.01 \\
\hline
\end{tabular}

${ }^{1}$ Multiparous Holstein cows were allowed ad libitum intake of a regular diet throughout the study (control, $n$ $=9$ ) or underwent $96 \mathrm{~h}$ of nutrient restriction (restricted, $\mathrm{n}=8$ ) by receiving a ration composed of $48 \%$ (DM basis) straw from 24 to $27 \pm 3$ DIM (mean $\pm \mathrm{SD}$ ). One healthy rear mammary quarter was injected with 50 $\mu \mathrm{g}$ of LPS (Escherichia coli O111:B4) $72 \mathrm{~h}$ after initiation of dietary treatments. Blood samples were collected at $-1,-0.5,1,2,4,6,10$, and $24 \mathrm{~h}$ relative to LPS injection.

${ }^{2} 72 \mathrm{~h}=$ average concentration at 1 and $0.5 \mathrm{~h}$ before LPS challenge; $\mathrm{AUC}_{10 \mathrm{~h}}$ and $\mathrm{AUC}_{24 \mathrm{~h}}=$ area under the curve during first $10 \mathrm{~h}$ after LPS (concentration units $\times 10 \mathrm{~h}$ ) and during first $24 \mathrm{~h}$ after LPS (concentration units $\times 24 \mathrm{~h}$ ). 
A

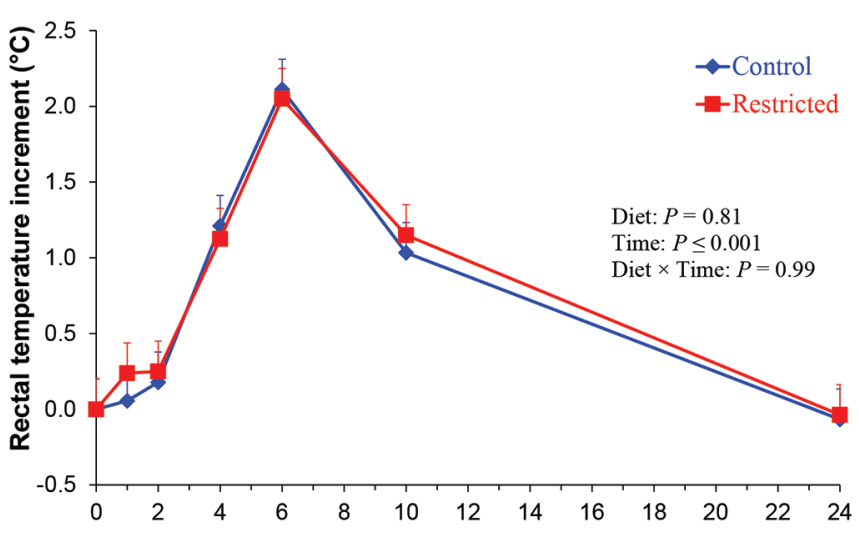

C

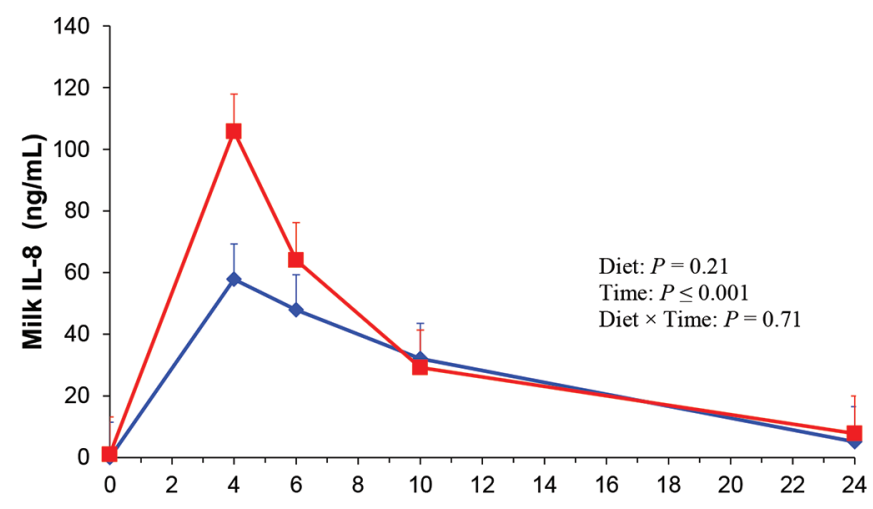

E

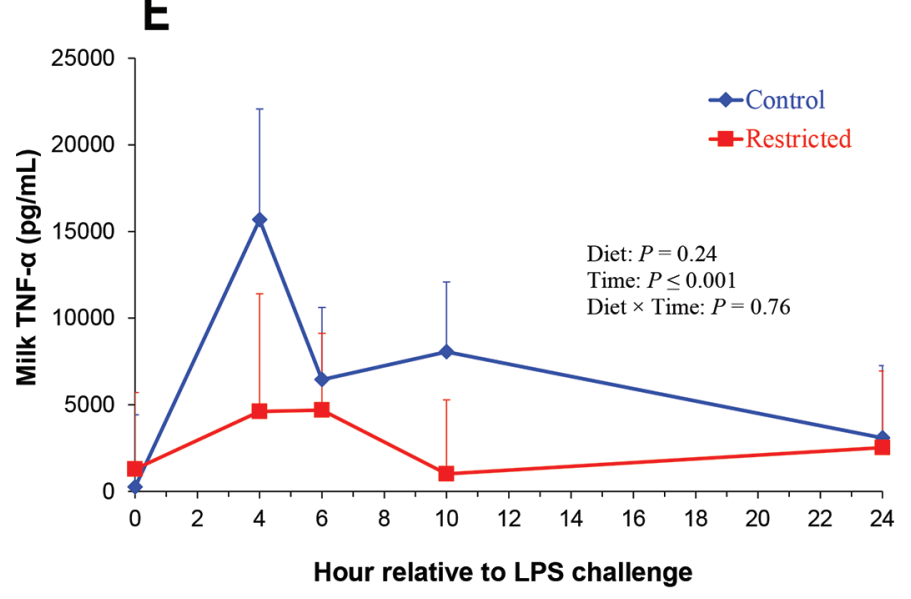

B

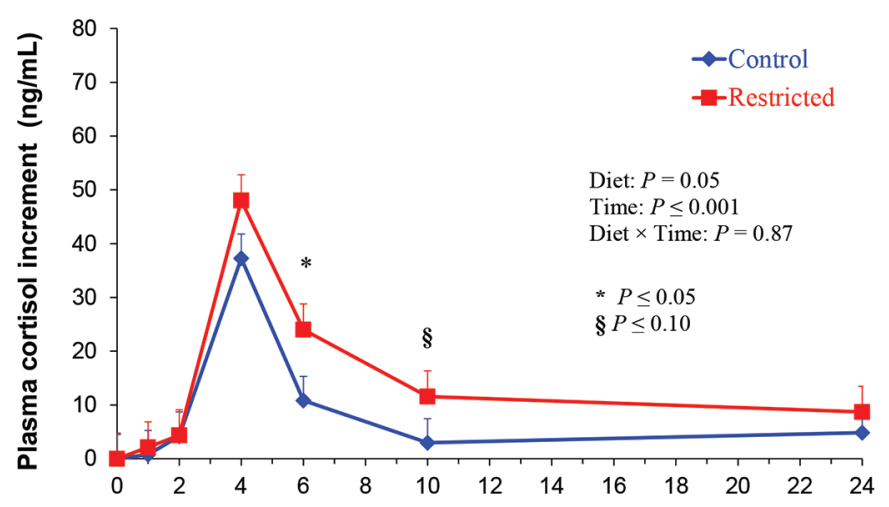

D
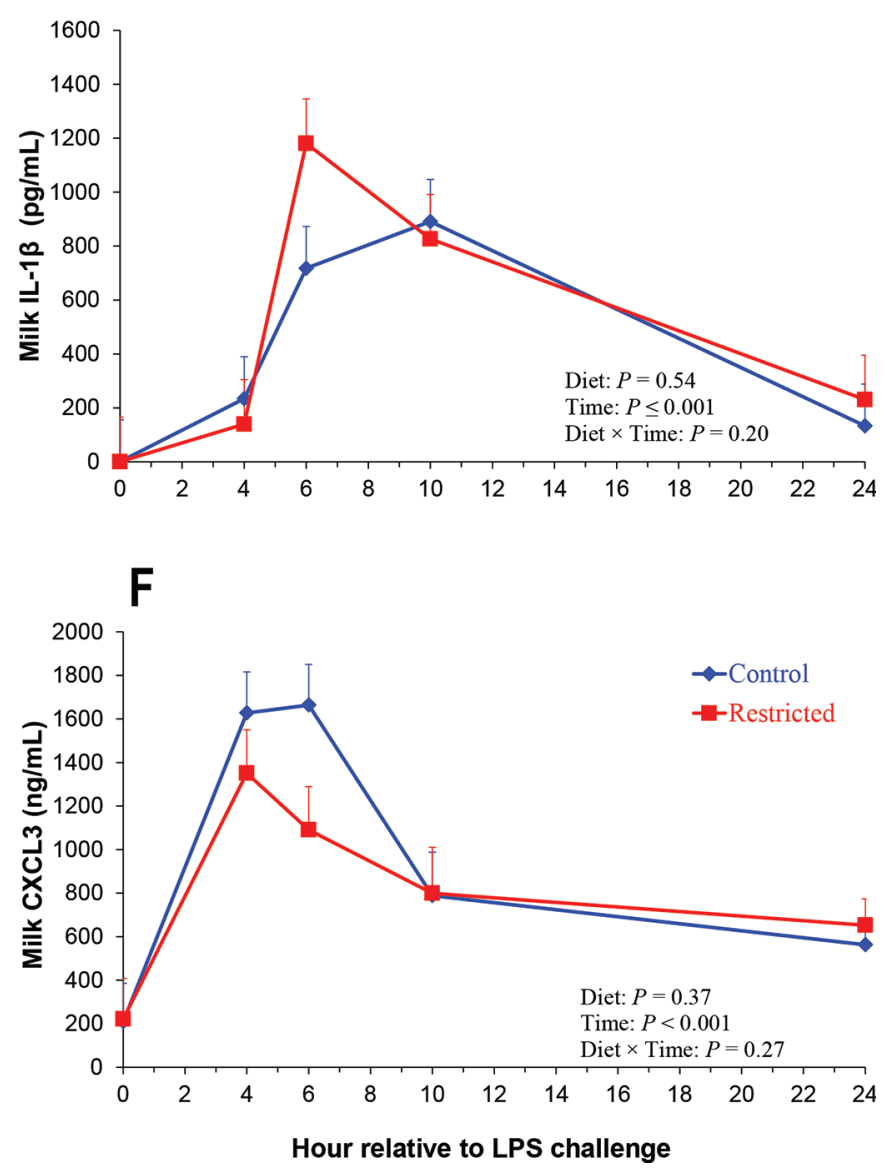

Figure 3. Effects of nutrient restriction on rectal temperature increment (A), plasma cortisol increment (B), milk IL-8 (C), IL-1 $\beta$ (D), tumor necrosis factor (TNF)- $\alpha(\mathrm{E})$, and chemokine (C-X-C motif) ligand 3 (CXCL3; F) concentrations in response to LPS challenge in early-lactation cows. Multiparous Holstein cows were allowed ad libitum intake of a regular diet throughout the study (control, $\mathrm{n}=9$ ) or underwent $4 \mathrm{~d}$ of nutrient restriction (restricted, $\mathrm{n}=8$ ) by receiving a ration composed of $48 \%$ (DM basis) straw from 24 to $27 \pm 3$ DIM (mean \pm SD). One healthy rear mammary quarter was injected with $50 \mu \mathrm{g}$ of LPS (Escherichia coli O111:B4) $72 \mathrm{~h}$ after initiation of dietary treatments. Rectal temperature was recorded and blood samples collected before and at 1,2, 4, 6, 10, and $24 \mathrm{~h}$; foremilk milk samples were collected from the injected mammary quarter before and at 4, 6, 10, and $24 \mathrm{~h}$ relative to LPS administration. Values are $\mathrm{LSM} \pm \mathrm{SEM}$. 
ergy balance induced in early-lactation cows, few of the inflammation indicators measured in this study differed between normally fed and restricted cows. Nonetheless, metabolic responses to LPS differed between the 2 treatments, suggesting a prioritization of nutrient partition to sustain the immune response during an acute intramammary inflammation.

\section{Early Lactation and Responses to Nutrient Restriction}

Production and most indicators of metabolic status did not differ between CONT and REST during the first $3 \mathrm{wk}$ of lactation before restriction. Exceptions were a trend for greater plasma BHB on wk 1 observed in REST, and increased milk content in cis-9 18:1, which is potentially derived from adipose tissue, and decreased in FA synthesized de novo ( $\Sigma 10: 0$ to 15:0) during the first 2 wk of lactation (data not shown). These differences may be explained by the trend for greater prepartum BCS observed in REST cows.
The experimental undernutrition model used in the present study (diet containing $48 \%$ straw, DM basis) induced repeatable decreases in DMI, energy balance, milk production, and rapid modifications of metabolite and hormonal profiles, and is in agreement with previous research that used a diet containing $60 \%$ straw (Bjerre-Harpøth et al., 2012). Per design, the metabolic status was profoundly altered in REST before initiation of LPS challenge (i.e., elevated NEFA, BHB, and low insulin and glucose concentrations in plasma). For these reasons, the nutritional challenge during early lactation may be better suited to assess the ramifications of undernutrition and metabolic imbalance on immune activation at the whole-animal level compared with later in lactation (Perkins et al., 2002; Moyes et al., 2009).

\section{Responses to Intramammary LPS}

Immune Activation. Immune activation following the intramammary LPS injection was confirmed by in-
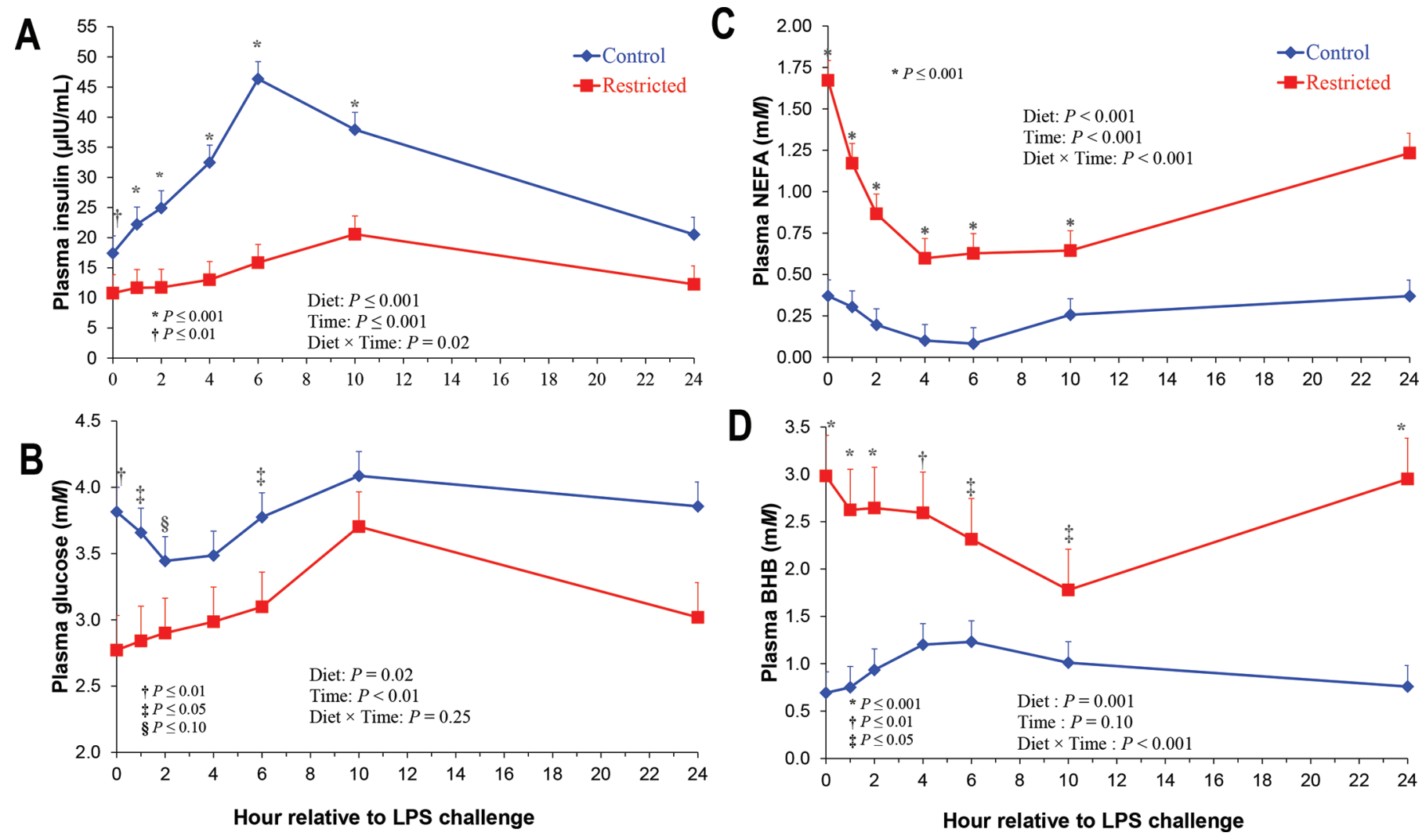

Figure 4. Effects of nutrient restriction on plasma concentrations of (A) insulin, (B) glucose, (C) nonesterified fatty acids, and (D) BHB in response to LPS challenge in early-lactation cows. Multiparous Holstein cows were allowed ad libitum intake of a regular diet throughout the study (control, $\mathrm{n}=9$ ) or underwent $4 \mathrm{~d}$ of nutrient restriction (restricted, $\mathrm{n}=8$ ) by receiving a ration composed of $48 \%$ (DM basis) straw from 24 to $27 \pm 3$ DIM (mean \pm SD). One healthy rear mammary quarter was injected with $50 \mu \mathrm{g}$ of LPS (Escherichia coli O111:B4) 72 h after initiation of dietary treatments. Blood samples collected before and at 1, 2, 4, 6, 10, and $24 \mathrm{~h}$ relative to LPS injection. Values are LSM \pm SEM. 
creases in rectal temperature, composite SCC, foremilk IL-8, IL-1 $\beta$, TNF- $\alpha$, and CXCL3 concentrations, and anecdotal observation of mammary gland symptoms (e.g., swelling, hardness, redness, and soreness) and modified quarter milk appearance (clots and yellowish color). Concerning the effect of diet on indicators of inflammatory response, only cortisol response AUC and composite milk SCC differed between CONT and REST. These limited effects in early-lactation cows are in agreement with previous research during mid lactation involving partial feed restriction and experimental inflammation by LPS or Streptococcus uberis infection (Perkins et al., 2002; Moyes et al., 2009).

Restricted cows had greater composite milk SCC on the day following LPS injection than CONT, but the biological implications of this observation are uncertain. The SCC difference is not explained by a concentration effect due to differences in milk volume because the total number of secreted somatic cells was higher in REST than in CONT cows on the same day, despite their lower milk yield. Our results contrast with those obtained in mid-lactation cows restricted to $80 \%$ of energy requirements for $2 \mathrm{wk}$, followed by an intramammary LPS challenge, where no difference in quarter milk SCC was observed (Perkins et al., 2002), and to the decreased SCC response to LPS when hyperketonemia was induced in mid-lactation cows via prolonged i.v. BHB perfusion (Zarrin et al., 2014a). Several factors may explain the enhanced SCC and total SC secretion in REST cows. Mammary epithelial integrity may be altered in early-lactation cows undergoing extreme feed restriction, potentially facilitating the transfer of plasma constituents and PMN into alveolar milk. Moderate feed restriction promotes exfoliation of epithelial cells in milk, and mammary epithelium permeability increases during severe restriction (Stumpf et al., 2013; Herve et al., 2019). Intramammary LPS reduces integrity of the alveolar blood-milk barrier (Wellnitz et al., 2013) via the opening of tight junctions and potential cell damage (Wellnitz et al., 2016). Restricted cows may have been in a proinflammatory state because of their extremely low DMI, high plasma NEFA, and ketosis. In fact, previous research has shown that selected plasma markers of inflammation are increased before the onset of and during ketosis in periparturient cows (Abuajamieh et al., 2016). Some fatty acids at high concentrations are agonists of toll-like receptor 4 (TLR4), the pathogen recognition receptor on host cells that interacts with LPS to elicit the inflammatory response (Shi et al., 2006; Sordillo and Mavangira, 2014).

Nonetheless, the greater milk SCC observed in REST cows after LPS injection does not imply an enhanced immune response, because leukocyte function was probably modified in REST. For instance, leukocyte phagocytic activity is impaired in early-lactation cows experiencing negative energy balance and elevated plasma NEFA (Hammon et al., 2006) and the severity of experimental E. coli mammary infection seems more pronounced in ketotic cows (Kremer et al., 1993), as leukocyte chemotaxis (Suriyasathaporn et al., 1999) and respiratory burst (Hoeben et al., 1997) are affected by $\mathrm{BHB}$ at concentrations lower than those observed in REST cows at the time of LPS challenge.

Metabolic Responses to Immune Activation. The systemic effects of LPS challenge on fat and carbohydrate metabolism might be mediated by transient increases in circulating cortisol, $\mathrm{TNF}-\alpha$, and other proinflammatory cytokines that modify secretion of insulin, glucagon, and other hormones (Steiger et al., 1999; Hoeben et al., 2000; Waldron et al., 2003a; Kushibiki, 2011), as well as the response of target tissues to hormones such as insulin (Zarrin et al., 2014b). Direct effects of intramammary LPS on whole-body metabolism should have been minimal in our study because previous research using greater LPS doses did not detect LPS in the systemic circulation after its administration into the mammary gland cistern and reported only short-term increases in plasma LPS after i.v. injection (Hoeben et al., 2000).

The increment in cortisol concentrations above prechallenge baseline and cortisol response AUC were greater for REST than CONT cows (Figure 3B and Table 2). It is unknown whether these differences in cortisol response have contributed to the metabolic effects of LPS observed in our study. Cortisol concentrations per se did not differ between CONT and REST cows (Supplemental Figure S3B; https://doi.org/10 $.3168 /$ jds.2018-15446); only the cortisol increment above pre-challenge baseline differed. The increase in plasma insulin concentration was delayed, and insulin AUC in response to LPS was attenuated in nutrientrestricted early-lactation dairy cows. This effect may be explained by the hypoglycemic state of REST cows.

Plasma glucose increased gradually after LPS in REST, leading to a positive glucose response AUC, despite a concomitant insulin increase. A transient increase in plasma glucose concentration has been observed in response to LPS injection (Zarrin et al., 2014b; Kvidera et al., 2017). Because REST cows were in early lactation, nutrient-restricted and ketotic at the time of LPS challenge, glycogenolysis could not have been a source of glucose, because depletion of liver glycogen reserves precedes experimentally induced ketosis (Veenhuizen et al., 1991). Previous research suggests that hepatic conversion of propionate to glucose may be upregulated after LPS challenge in fed mid-lactation cows (Waldron et al., 2003a). The increase in plasma urea concentration observed until $4 \mathrm{~h}$ after LPS injection in our study 
probably reflects enhanced reliance on AA to sustain inflammatory response and gluconeogenesis (Gifford et al., 2012; Greco et al., 2015).

Plasma NEFA decreased sharply after LPS injection for both CONT and REST cows. It has been suggested that plasma NEFA changes that occur postLPS challenge are due to hyperinsulinemia (Kvidera et al., 2017), but a NEFA decrease after LPS injection preceded the plasma insulin increment in REST cows. Consequently, the typical inverse diurnal relationship between plasma NEFA and insulin (Allen, 2014) is not observed in REST cows challenged with intramammary LPS. Restricted cows were ketotic at the time of LPS injection. The decrease in plasma BHB post-LPS challenge is in agreement with the concomitant reduction in plasma NEFA and it may result from downregulated liver ketogenesis, increased ketone utilization, or a combination of both, and may constitute a glucose-sparing strategy (Zarrin et al., 2014b; Kvidera et al., 2017). The reduction of plasma BHB preceded significant time effects in plasma insulin and glucose, as observed for plasma NEFA. Other factors must have mediated early changes in plasma NEFA and BHB concentrations after LPS challenge in REST cows.

In CONT cows, plasma BHB concentrations increased after LPS, despite decreased NEFA and increased insulin, together with a transient decrease in glucose. In CONT cows, but not in REST cows, these profiles share common patterns with diurnal variations related to morning feed intake (Allen, 2014; Piantoni et al., 2015). Therefore, postprandial effects may have played a role in plasma metabolite and insulin profiles observed in CONT cows during the first hours after LPS challenge because fresh TMR was offered after morning milking. Nonetheless, previous research suggests that metabolic effects of high LPS doses are independent of feed intake (Steiger et al., 1999). The potential intake effects should be minor in REST cows because of the low DMI, low concentrate content, and low fermentability of the high-straw TMR. Time changes in plasma metabolite and insulin concentrations in REST cows should have been driven by LPS-induced inflammation.

The increase in plasma glucose and insulin concentrations concomitant with inflammatory response (i.e., fever, increased cortisol, milk IL-8, IL-1 $\beta$, TNF- $\alpha$, and CXCL3) indicate the establishment of insulin resistance in both CONT and REST cows. Insulin resistance constitutes a homeorhetic adaptation to support the massive glucose requirements of an acute inflammation response and is probably mediated by sharp increases in systemic cortisol and inflammation cytokines, such as TNF- $\alpha$ (Waldron et al., 2003a; Kushibiki, 2011; Vernay et al., 2012; Moyes et al., 2014; Zarrin et al., 2014b;
Kvidera et al., 2017). Restricted cows were probably in an insulin-resistant state before the LPS challenge, due to hormonal changes and elevated circulating NEFA (Pires et al., 2007) and ceramides (Davis et al., 2017). Acute adaptations may have allowed REST cows to direct glucose and other nutrients to immune activation, as suggested by plasma metabolite and insulin profiles during the hours following intramammary LPS injection. Nonetheless, the ability to cope with prolonged or repeated challenges and resulting metabolic modifications may be limited (Waldron et al., 2003a; Bradford et al., 2015; Kvidera et al., 2017), for instance, in the case of chronic inflammation and intake depression during early lactation, which may disrupt homeostatic capacity of the dairy cow.

\section{CONCLUSIONS}

Experimentally induced undernutrition in earlylactation Holstein cows had limited effects on animallevel indicators of acute inflammation measured in this study, as previously observed in mid-lactation cows. The short-term response following intramammary LPS injection suggests modifications of nutrient partitioning to support immune activation via an apparent establishment of insulin resistance in both CON and REST cows, despite intense lipomobilization, ketosis, and limited availability of precursors for glucose synthesis in REST cows. Inflammation during early lactation (acute or chronic) may impose a metabolic burden due to aggravated insulin resistance and utilization of glucose and other limiting nutrients to support immune activation, and further challenge the homeostasis mechanisms of early-lactation cows.

\section{ACKNOWLEDGMENTS}

The authors thank the staff at Herbipôle Research Unit (INRA, UE1414, Theix, France) for animal care and sampling; D. Bany, S. Bes, C. Labonne, E. Tixier, and M. Tourret (INRA, UMR1213, Saint-Genès-Champanelle, France) for sample collection and laboratory analyses; P. Rainard (INRA, UMR1282 ISP, Nouzilly, France) for valuable discussions on experimental design; M. Faure and C. Ravel (INRA, UMR1213, SaintGenès-Champanelle, France) for proposing cortisol sampling schedule and cortisol analyses, respectively. The authors are grateful to the Galilait laboratory (Clermont-Ferrand, France) for milk component, SCC, and microbiological analyses. This research was funded by GISA meta-program of INRA (Ruminflame and Longhealth projects). 


\section{REFERENCES}

Abuajamieh, M., S. K. Kvidera, M. V. S. Fernandez, A. Nayeri, N. C. Upah, E. A. Nolan, S. M. Lei, J. M. DeFrain, H. B. Green, K. M. Schoenberg, W. E. Trout, and L. H. Baumgard. 2016. Inflammatory biomarkers are associated with ketosis in periparturient Holstein cows. Res. Vet. Sci. 109:81-85.

Albaaj, A., G. Foucras, and D. Raboisson. 2017. High somatic cell counts and changes in milk fat and protein contents around insemination are negatively associated with conception in dairy cows. Theriogenology 88:18-27.

Allen, M. S. 2014. Drives and limits to feed intake in ruminants. Anim. Prod. Sci. 54:1513-1524.

Bell, A. W., and D. E. Bauman. 1997. Adaptations of glucose metabolism during pregnancy and lactation. J. Mammary Gland Biol. Neoplasia 2:265-278.

Bjerre-Harpøth, V., N. C. Friggens, V. M. Thorup, T. Larsen, B. M. Damgaard, K. L. Ingvartsen, and K. M. Moyes. 2012. Metabolic and production profiles of dairy cows in response to decreased nutrient density to increase physiological imbalance at different stages of lactation. J. Dairy Sci. 95:2362-2380.

Boissy, A., and M. F. Bouissou. 1994. Effects of androgen treatment on behavioral and physiological responses of heifers to fear-eliciting situations. Horm. Behav. 28:66-83.

Bouvier-Muller, J., C. Allain, F. Enjalbert, G. Tabouret, D. Portes, C. Caubet, C. Tasca, G. Foucras, and R. Rupp. 2016. Response to dietary-induced energy restriction in dairy sheep divergently selected for resistance or susceptibility to mastitis. J. Dairy Sci. 99:480-492.

Bradford, B. J., K. Yuan, J. K. Farney, L. K. Mamedova, and A. J. Carpenter. 2015. Invited review: Inflammation during the transition to lactation: New adventures with an old flame. J. Dairy Sci. 98:6631-6650.

Cardoso, F. C., W. Sears, S. J. LeBlanc, and J. K. Drackley. 2011. Technical note: Comparison of 3 methods for analyzing areas under the curve for glucose and nonesterified fatty acids concentrations following epinephrine challenge in dairy cows. J. Dairy Sci. 94:6111-6115.

Davis, A. N., J. L. Clegg, C. A. Perry, and J. W. McFadden. 2017. Nutrient restriction increases circulating and hepatic ceramide in dairy cows displaying impaired insulin tolerance. Lipids 52:771780.

Doepel, L., G. E. Lobley, J. F. Bernier, P. Dubreuil, and H. Lapierre 2009. Differences in splanchnic metabolism between late gestation and early lactation dairy cows. J. Dairy Sci. 92:3233-3243.

Gifford, C. A., B. P. Holland, R. L. Mills, C. L. Maxwell, J. K. Farney, S. J. Terrill, D. L. Step, C. J. Richards, L. O. Burciaga Robles, and C. R. Krehbiel. 2012. Growth and development symposium: Impacts of inflammation on cattle growth and carcass merit. J. Anim. Sci. 90:1438-1451.

Greco, L. F., J. T. N. Neto, A. Pedrico, R. A. Ferrazza, F. S. Lima, R. S. Bisinotto, N. Martinez, M. Garcia, E. S. Ribeiro, G. C. Gomes, J. H. Shin, M. A. Ballou, W. W. Thatcher, C. R. Staples, and J. E. P. Santos. 2015. Effects of altering the ratio of dietary n- 6 to n-3 fatty acids on performance and inflammatory responses to a lipopolysaccharide challenge in lactating Holstein cows. J. Dairy Sci. 98:602-617.

Gross, J., H. A. van Dorland, R. M. Bruckmaier, and F. J. Schwarz. 2011. Performance and metabolic profile of dairy cows during a lactational and deliberately induced negative energy balance with subsequent realimentation. J. Dairy Sci. 94:1820-1830.

Hammon, D. S., I. M. Evjen, T. R. Dhiman, J. P. Goff, and J. L. Walters. 2006. Neutrophil function and energy status in Holstein cows with uterine health disorders. Vet. Immunol. Immunopathol. 113:21-29.

Hertl, J. A., Y. H. Schukken, L. W. Tauer, F. L. Welcome, and Y. T. Gröhn. 2018. Does clinical mastitis in the first 100 days of lactation 1 predict increased mastitis occurrence and shorter herd life in dairy cows? J. Dairy Sci. 101:2309-2323.

Herve, L., H. Quesnel, M. Veron, J. Portanguen, J. J. Gross, R. M. Bruckmaier, and M. Boutinaud. 2019. Milk yield loss in response to feed restriction is associated with mammary epithelial cell exfoliation in dairy cows. J. Dairy Sci. 102:2670-2685. https://doi.org/ 10.3168/jds.2018-15398

Hoeben, D., C. Burvenich, E. Trevisi, G. Bertoni, J. Hamann, R. M. Bruckmaier, and J. W. Blum. 2000. Role of endotoxin and TNF- $\alpha$ in the pathogenesis of experimentally induced coliform mastitis in periparturient cows. J. Dairy Res. 67:503-514.

Hoeben, D., R. Heyneman, and C. Burvenich. 1997. Elevated levels of $\beta$-hydroxybutyric acid in periparturient cows and in vitro effect on respiratory burst activity of bovine neutrophils. Vet. Immunol. Immunopathol. 58:165-170.

INRA. 2007. Alimentation des bovins, ovins et caprins. Besoins des Animaux-Valeur des aliments. Editions Quae Versailles, Paris, France.

Kremer, W. D. J., E. N. Noordhuizen-Stassen, F. J. Grommers, Y. H. Schukken, R. Heeringa, A. Brand, and C. Burvenich. 1993. Severity of experimental Escherichia coli mastitis in ketonemic and nonketonemic dairy cows. J. Dairy Sci. 76:3428-3436.

Kushibiki, S. 2011. Tumor necrosis factor-alpha-induced inflammatory responses in cattle. Anim. Sci. J. 82:504-511.

Kvidera, S. K., E. A. Horst, M. Abuajamieh, E. J. Mayorga, M. V. S. Fernandez, and L. H. Baumgard. 2017. Glucose requirements of an activated immune system in lactating Holstein cows. J. Dairy Sci. 100:2360-2374.

Lerch, S., A. Ferlay, D. Pomies, B. Martin, J. A. A. Pires, and Y. Chilliard. 2012. Rapeseed or linseed supplements in grass-based diets: Effects on dairy performance of Holstein cows over 2 consecutive lactations. J. Dairy Sci. 95:1956-1970.

Martinez, N., L. D. P. Sinedino, R. S. Bisinotto, E. S. Ribeiro, G. C. Gomes, F. S. Lima, L. F. Greco, C. A. Risco, K. N. Galvão, D. Taylor-Rodriguez, J. P. Driver, W. W. Thatcher, and J. E. P. Santos. 2014. Effect of induced subclinical hypocalcemia on physiological responses and neutrophil function in dairy cows. J. Dairy Sci. 97:874-887.

Moyes, K. M. 2015. Triennial Lactation Symposium: Nutrient partitioning during intramammary inflammation: A key to severity of mastitis and risk of subsequent diseases? J. Anim. Sci. 93:55865593.

Moyes, K. M., J. K. Drackley, J. L. Salak-Johnson, D. E. Morin, J. C. Hope, and J. J. Loor. 2009. Dietary-induced negative energy balance has minimal effects on innate immunity during a Streptococcus uberis mastitis challenge in dairy cows during midlactation. J. Dairy Sci. 92:4301-4316.

Moyes, K. M., T. Larsen, P. Sørensen, and K. L. Ingvartsen. 2014 Changes in various metabolic parameters in blood and milk during experimental Escherichia coli mastitis for primiparous Holstein dairy cows during early lactation. J. Anim. Sci. Biotechnol. 5:47.

Paape, M. J., D. D. Bannerman, X. Zhao, and J.-W. Lee. 2003. The bovine neutrophil: Structure and function in blood and milk. Vet. Res. 34:597-627.

Perkins, K. H., M. J. VandeHaar, J. L. Burton, J. S. Liesman, R. J. Erskine, and T. H. Elsasser. 2002. Clinical responses to intramammary endotoxin infusion in dairy cows subjected to feed restriction. J. Dairy Sci. 85:1724-1731.

Piantoni, P., C. M. Ylioja, and M. S. Allen. 2015. Feed intake is related to changes in plasma nonesterified fatty acid concentration and hepatic acetyl CoA content following feeding in lactating dairy cows. J. Dairy Sci. 98:6839-6847.

Pires, J. A. A., C. Delavaud, Y. Faulconnier, D. Pomies, and Y. Chilliard. 2013. Effects of body condition score at calving on indicators of fat and protein mobilization of periparturient Holstein-Friesian cows. J. Dairy Sci. 96:6423-6439.

Pires, J. A. A., A. H. Souza, and R. R. Grummer. 2007. Induction of hyperlipidemia by intravenous infusion of tallow emulsion causes insulin resistance in Holstein cows. J. Dairy Sci. 90:2735-2744.

Schukken, Y. H., J. Günther, J. Fitzpatrick, M. C. Fontaine, L. Goetze, O. Holst, J. Leigh, W. Petzl, H. J. Schuberth, A. Sipka, D. G. E. Smith, R. Quesnell, J. Watts, R. Yancey, H. Zerbe, A. Gurjar, R. N. Zadoks, and H. M. Seyfert. 2011. Host-response patterns of intramammary infections in dairy cows. Vet. Immunol. Immunopathol. 144:270-289. 
Shi, H., M. V. Kokoeva, K. Inouye, I. Tzameli, H. Yin, and J. S. Flier. 2006. TLR4 links innate immunity and fatty acid-induced insulin resistance. J. Clin. Invest. 116:3015-3025.

Shuster, D. E., E. K. Lee, and M. E. Kehrli. 1996. Bacterial growth, inflammatory cytokine production, and neutrophil recruitment during coliform mastitis in cows within ten days after calving, compared with cows at midlactation. Am. J. Vet. Res. 57:1569-1575.

Sordillo, L. M., and V. Mavangira. 2014. The nexus between nutrient metabolism, oxidative stress and inflammation in transition cows. Anim. Prod. Sci. 54:1204-1214.

Steiger, M., M. Senn, G. Altreuther, D. Werling, F. Sutter, M. Kreuzer, and W. Langhans. 1999. Effect of a prolonged low-dose lipopolysaccharide infusion on feed intake and metabolism in heifers. J. Anim. Sci. 77:2523-2532.

Stumpf, M. T., V. Fischer, C. M. McManus, G. J. Kolling, M. B. Zanela, C. S. Santos, A. S. Abreu, and P. Montagner. 2013. Severe feed restriction increases permeability of mammary gland cell tight junctions and reduces ethanol stability of milk. Animal $7: 1137-1142$.

Suriyasathaporn, W., A. J. J. M. Daemen, E. N. NoordhuizenStassen, S. J. Dieleman, M. Nielen, and Y. H. Schukken. 1999. $\beta$-Hydroxybutyrate levels in peripheral blood and ketone bodies supplemented in culture media affect the in vitro chemotaxis of bovine leukocytes. Vet. Immunol. Immunopathol. 68:177-186.

Valldecabres, A., J. A. A. Pires, and N. Silva-del-Río. 2018. Effect of prophylactic oral calcium supplementation on postpartum mineral status and markers of energy balance of multiparous Jersey cows. J. Dairy Sci. 101:4460-4472.

Veenhuizen, J. J., J. K. Drackley, M. J. Richard, T. P. Sanderson, L. D. Miller, and J. W. Young. 1991. Metabolic changes in blood and liver during development and early treatment of experimental fatty liver and ketosis in cows. J. Dairy Sci. 74:4238-4253.

Vernay, M. C. M. B., O. Wellnitz, L. Kreipe, H. A. van Dorland, and R. M. Bruckmaier. 2012. Local and systemic response to intramammary lipopolysaccharide challenge during long-term manipulated plasma glucose and insulin concentrations in dairy cows. J. Dairy Sci. 95:2540-2549.

Waldron, M. R., T. Nishida, B. J. Nonnecke, and T. R. Overton. 2003a. Effect of lipopolysaccharide on indices of peripheral and hepatic metabolism in lactating cows. J. Dairy Sci. 86:3447-3459.

Waldron, M. R., B. J. Nonnecke, T. Nishida, R. L. Horst, and T. R. Overton. 2003b. Effect of lipopolysaccharide infusion on serum macromineral and vitamin D concentrations in dairy cows. J. Dairy Sci. 86:3440-3446.

Wellnitz, O., E. T. Arnold, M. Lehmann, and R. M. Bruckmaier. 2013. Short communication: Differential immunoglobulin transfer during mastitis challenge by pathogen-specific components. J. Dairy Sci. 96:1681-1684.

Wellnitz, O., C. Zbinden, X. Huang, and R. M. Bruckmaier. 2016. Short communication: Differential loss of bovine mammary epithelial barrier integrity in response to lipopolysaccharide and lipoteichoic acid. J. Dairy Sci. 99:4851-4856.

Zarrin, M., O. Wellnitz, H. A. van Dorland, and R. M. Bruckmaier. 2014a. Induced hyperketonemia affects the mammary immune response during lipopolysaccharide challenge in dairy cows. J. Dairy Sci. 97:330-339.

Zarrin, M., O. Wellnitz, H. A. van Dorland, J. J. Gross, and R. M. Bruckmaier. 2014b. Hyperketonemia during lipopolysaccharide-induced mastitis affects systemic and local intramammary metabolism in dairy cows. J. Dairy Sci. 97:3531-3541. 